\title{
Urbanization-Related Changes Over the Last 20 Years in Occurrence, Sources and Human Health Risks of Soil PAHs in Rural Tianjin, China
}

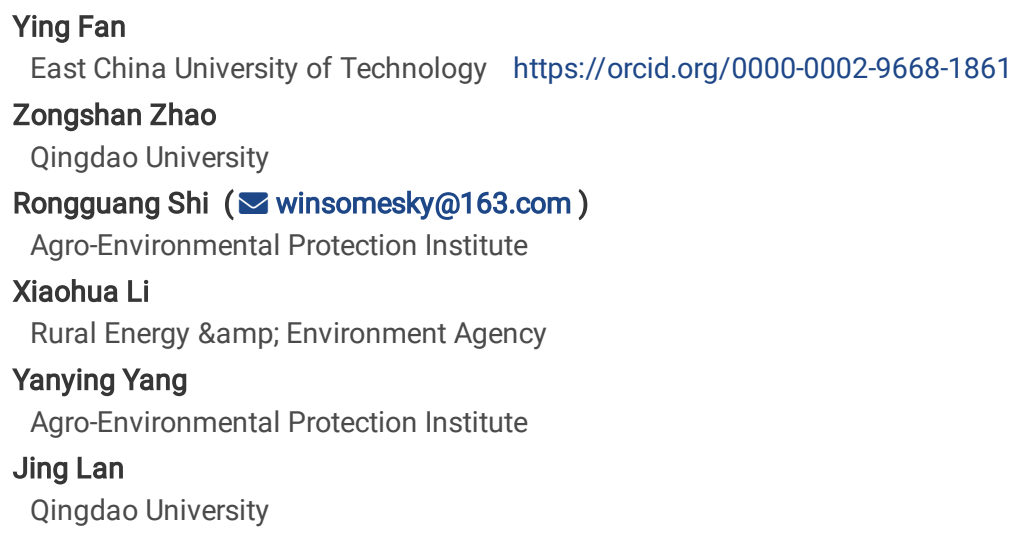

Research Article

Keywords: urbanization, polycyclic aromatic hydrocarbon, soil, human health risk, positive matrix factorization

Posted Date: April 19th, 2021

DOI: https://doi.org/10.21203/rs.3.rs-393371/v1

License: (c) (7) This work is licensed under a Creative Commons Attribution 4.0 International License. Read Full License

Version of Record: A version of this preprint was published at Environmental Chemistry Letters on July 20th, 2021. See the published version at https://doi.org/10.1007/s10311-021-01264-1. 


\section{Abstract}

Polycyclic aromatic hydrocarbons (PAHs), one of the key pollutants in urban areas, have presented a great risk to the resident health. So far, however, studies in-depth on changes of local PAH emissions and associated health risks closely related to urbanization are scarce. Here, the concentrations of PAHs were determined in 57 surface soil samples obtained from two rural districts in 2018 in Tianjin, China. The sources, risks and the linkage between urbanization and PAH contamination of soil PAHs in 2018 were compared with the data in 2001 from a previous study to investigate the changes related to urbanization effects. The temporal changes in the concentrations and composition of PAHs for two districts were similar. The increased total concentrations of soil PAHs could be attributed to the fact that ANT and DahA became the dominated compounds, which was related to changes of the PAH sources. Results of the positive matrix factorization model suggest that the major sources of soil PAHs changed from coal combustion (32.9\%), petroleum sources (32.1\%), and traffic sources (22.1\%) in 2001 to traffic sources (63.7\%) and petroleum and biomass combustion (18.7\%) in 2018. Results from incremental lifetime cancer risk (ILCR) model showed that the carcinogenic risk of soil PAHs to residents also increased from safe level to low level, and dermal contact was the prevailing pathway of PAH exposure. The increase in cancer risks were mainly related to the alterations of PAH sources.

\section{Introduction}

Polycyclic aromatic hydrocarbons (PAHs), a class of ubiquitous environmental organic contaminants, primarily stem from anthropogenic sources such as oil spills, vehicle emissions, fossil fuel and biomass combustion, industrial processes, as well as chemical manufacturing, and also from natural movements such as volcanic activity, forest fires, and diagenesis (Nisbet and Lagoy, 1992; Wang et al., 2013a). PAHs have been widely concerned owing to their ubiquitous environmental occurrences, bioaccumulation, and potential adverse effects to human (Santodonato et al., 1981). 16 PAHs has been proposed as priority pollutants by the United States Environmental Protection Agency (US EPA) (Harvey, 1991). Among these components, low molecular weight (LMW) PAHs with two or three aromatic rings are considered non-carcinogenic, while seven high molecular weight (HMW) PAHs containing 4 to 6 rings are classified as carcinogenic congeners (Waqas et al., 2014). Once released into the environment, PAHs may undergo transportation over long distances through water and air and thus remain globally in soils, sediments, waters, and atmospheres (Daskalakis and O'Connor, 1995; Manariotis et al., 2011). PAHs are resistant to degradation and prone to be absorbed by soil particles (Wang et al., 2017; Wilcke, 2007), which makes soils capable to be an important "PAH sink", burying more than $90 \%$ of the environmental PAH loads (Hu et al., 2013b; Wild and Jones, 1995).

In general, the major cause of global PAH pollution is massive emissions from human activities related to urbanization (Harrison et al., 1996), although there are some non-anthropogenic PAH sources. Many developing countries, especially China, have been currently in a changeover period between the rise of urbanization and rapid development. Due to massive urbanization and industrialization, urban areas are densely populated and are accompanied by several phenomena such as population agglomeration, increased construction of industrial facilities, and surge of vehicle use, concurrently producing large amounts of PAHs transported into urban soils by atmospheric deposition (Bozlaker et al., 2008; Dickhut et al., 2000). Additionally, PAH distribution in urban soils is primarily attributed to the type and location of their sources (Liu et al., 2010; Peng et al., 2016b). Therefore, the intensified human activities related to urban development may alter the compositions and distribution of PAHs. And these alterations probably induce additional human health risks due to different components having widely varying toxicities, which has attracted little concern to date (Cao et al., 2017).

Urbanization is likely a key factor affecting the environmental behaviors of PAHs in urban soils (Wu et al., 2019). Wang et al. (2018) proposed that population density was one of the key factors for PAH levels in urban soils from Nanjing by investigating the correlations between PAH concentrations, factors related to urbanization, and soil properties. On the basis of soil PAH concentrations of a rapidly developing town in Southern Jiangsu in 2009 and 2014, Cao et al. (2017) ascribed the changes in levels, compositions, and sources of PAHs to urbanization process. Jensen et al. (Jensen et al., 2007) reported that PAH concentrations were higher in the more-populated and urbanized areas near Oslo in southern Norway than in the less-populated areas located in northern Norway. Moreover, sediment cores obtained from lakes and reservoirs and soil samples with different stages of urbanization or collected from different depths were also introduced to identify the relationships between environmental behaviors of PAHs and urbanization histories (Liu et al., 2010; Ni et al., 2011; Van Metre et al., 2000). Yet there are still few studies concerned on characterizing the influences of urbanization process on PAH concentrations, sources and health risks in urban soils within a certain period of time.

In this study, soil samples from two rural districts of Tianjin in 2018 were investigated for 16 US EPA priority PAHs to study their sources and cancer risks to local residents. Furthermore, the source apportionment and risk assessment of soil PAHs in the same areas in 2001 based on the data from a previous study (Wang et al., 2003; Zuo et al., 2007) were also introduced here to reveal the changes of emission sources and the concurrent variations as well as cancer risks during the past 20-year urbanization.

\section{Material And Methods}

\section{Sample collection}

As an important industrial city in Northern China, Tianjin is located at about $120 \mathrm{~km}$ east of Beijing and at the west of Bohai Bay. Jizhou district is located at $115 \mathrm{~km}$ north of Tianjin City and adjacent to Hebei province, with an area of $1590 \mathrm{~km}^{2}$ and a population of about 900,000 . From 2004 to 2016, the number of Jizhou GDP increased by 500\%. The tourism revenue of Jizhou district was up to 11 billion in 2016 . Ninghe district, with a population of about 400,000, is located in the east of Tianjin and close to Tianjin coastal new region, covering an area of about $1300 \mathrm{~km}^{2}$. From 2009 to 2018 , the Ninghe GDP grew about $230 \%$. A total of 57 surface soil samples $(0-10 \mathrm{~cm})$ from Jizhou district and Ninghe district were collected by a 
stainless-steel spade in 2018 (Fig. 1a), and they were subsequently kept in dark glass bottles and transported to laboratory. All samples were naturally dried at room temperature, then sieved through a 70-mesh sieve, and finally stored at $4{ }^{\circ} \mathrm{C}$ and dark conditions prior to analysis. The sampling map of those 33 soil samples $(0-10 \mathrm{~cm})$ from the same areas in 2001 was shown in Fig. 1b.

\section{Analysis of PAHs}

Sample extraction, cleanup, and instrumental conditions for PAHs followed our previous study (Shi et al., 2021). Soil samples were extracted in an accelerated solvent extraction, cleaned by a standard silica/aluminum gel column, and then concentrated prior to gas chromatography/mass selective detector analysis. A detailed description of the methods is provided in the Supplementary Content.

\section{Quality assurance and quality control}

Matrix-spiked recoveries, duplicates, and method blanks were processed and analyzed with soil samples. For the 16 spiked individual PAHs, the recoveries were from $70.4 \%$ to $117 \%$. The recoveries of deuterated PAHs ranged from $75 \%$ to $117 \%$. The method limits of detection (MDL) ranged from $0.01 \mathrm{ng} \mathrm{g}^{-1}$ to $0.46 \mathrm{ng} \mathrm{g}^{-1}$. A method blank (anhydrous sodium sulfate) was coupled with each batch of 12 samples, and the target compounds were under MDLs. All glassware was rinsed with dichloromethane and $n$-hexane and then baked at $450{ }^{\circ} \mathrm{C}$ for $4 \mathrm{~h}$.

\section{Results And Discussion}

\section{Levels and congener pattern of PAHs}

The concentrations of 16 individual PAHs, $n$-rings PAHs, 7 carcinogenic PAHs ( $\Sigma_{7 \text {-car }}$ PAHs) and total 16 PAHs $\left(\Sigma_{16}\right.$ PAHs) in soils from Jizhou district and Ninghe district in 2001 and 2018 are summarized in Table S1 and Table S2. For Jizhou district in 2001, the $\Sigma_{16}$ PAHs concentrations ranged from 241 to $777 \mathrm{ng} \mathrm{g}^{-1}$, with a mean value of $447 \mathrm{ng} \mathrm{g}^{-1}$. The concentrations of $\Sigma_{7 \text {-car }} \mathrm{PAHs}$ were in the range of 58.4 to $265 \mathrm{ng} \mathrm{g}^{-1}$, making up $38.1 \%$ of the $\Sigma_{16} \mathrm{PAHs}$ concentrations. Among, 2- and 5-ring PAHs were the predominated congeners with contributions of $37.0 \%$ and $28.6 \%$, respectively, followed by 3 (13.2\%), 4- (12.0\%), and 6-ring PAHs (9.2\%). LMW PAHs contributed about 50\% to the total PAHs. Among the detected PAHs, NAP, BbF, BkF, and BaP were the major compounds in soils, comprising $37.0 \%, 9.3 \%, 8.9 \%$, and $8.9 \%$ of the total PAHs, respectively. In 2018 , the concentrations of $\Sigma_{16}$ PAHs in soils from Jizhou district varied from 113 to $1064 \mathrm{ng} \mathrm{g}^{-1}$, with a mean of $711 \mathrm{ng} \mathrm{g}^{-1}$. The $\Sigma_{7 \text {-car }}$ PAHs comprised $24.5 \%$ of the total PAHs, varying from 25.3 to $364 \mathrm{ng} \mathrm{g}^{-1}$. The relative composition of PAHs ranked from high to low was as follows: 3-ring $(68.7 \%)>5$-ring $(20.8 \%)>4$-ring $(5.7 \%)>6$-ring (3.6\%) > 2ring (1.3\%). The ratio of LMW PAHs increased appreciably from $50 \%$ to $70 \%$. ANT and DahA were the dominated compounds, accounting for $59.1 \%$ and $16.5 \%$ of the total PAHs.

As to Ninghe district in 2001, for $\Sigma_{16} \mathrm{PAHs}$ and $\Sigma_{7-\mathrm{car}} \mathrm{PAHs}$ in soils, the concentration ranges were 240 to $2410 \mathrm{ng} \mathrm{g}^{-1}$ and 94.1 to $749 \mathrm{ng} \mathrm{g}^{-1}$, and their mean values were $624 \mathrm{ng} \mathrm{g}^{-1}$ and $219 \mathrm{ng} \mathrm{g}^{-1}$, respectively. The $\Sigma_{7-\text { car }} \mathrm{PAHs}$ accounted for $36.1 \%$ of the $\Sigma_{16}$ PAHs. The relative composition of PAHs decreased in the following order: 2-ring (36.7\%) > 5-ring (25.1\%) > 4-ring (14.4\%) > 3-ring (14.0\%) > 6-ring (9.7\%), and the percentage of LMW PAHs was about $50 \%$. In terms of the individual PAHs, NAP, BbF, PHE, BkF, and BaP were regarded as the predominated compounds, with the contributions of $36.7 \%$, $8.1 \%, 8.0 \%, 7.8 \%$ and $7.8 \%$, respectively. In 2018, the $\Sigma_{16}$ PAHs concentrations ranged from 202 to $1964 \mathrm{ng} \mathrm{g}^{-1}$ (mean $718 \mathrm{ng} \mathrm{g}^{-1}$ ), and the $\Sigma_{7-\text { car }} \mathrm{PAHs}$ concentrations were in range of 36.4 to $1496 \mathrm{ng} \mathrm{g}^{-1}$ and contributed to $28.8 \%$ of the total PAHs. 2-, 3-, 4-, 5- and 6-ring PAHs accounted for $2.5 \%, 62.7 \%$, $5.8 \%, 25.0 \%$ and $4.0 \%$, respectively. The ratio of LMW PAHs increased to $65 \%$. In addition, ANT and DahA were the major compounds, accounting for $47.2 \%$ and $15.9 \%$ of the total PAHs.

In summary, the temporal changes in concentrations and compositions of 16 PAHs for Jizhou district and Ninghe district between 2001 and 2018 were obvious and similar. Over this period, the concentrations of $\Sigma_{16} \mathrm{PAHs}$ of both districts increased, while the $\Sigma_{7 \text {-car }} \mathrm{PAHs}$ concentrations decreased or increased slightly. Moreover, the percentage of 2-ring PAHs fell from its peak to its trough, and the percentage of 4-ring PAHs also decreased, but the percentage of 3-ring PAHs increased significantly. The ratio of LMW PAHs increased appreciably. ANT and DahA, instead of NAP, BbF, BkF, and BaP, became the dominated compounds. The concentrations of ANT increased dramatically, while NAP and the HMW PAHs, except for DahA and BaP, decreased substantially. Although PAHs are characterized persistently, their removal from soils attributed to photolysis and chemical degradation, biodegradation and volatilization cannot be neglected (Haritash and Kaushik, 2009). Thus, previous studies found that the concentrations of PAHs decreased substantially after burying in soils for a long time (Cao et al., 2017; Choi, 2014). Moreover, PAHs with different rings present different environmental behaviors in soils (Wild and Jones, 1995). HMW PAHs tend to bury in soils for a longer period of time (Wang et al., 2011), and the degradation rate decreases with increasing molecular weight (Sun et al., 2014). LMW PAHs are more readily to be photodegraded and biodegraded (Jones et al., 1989; Wilcke et al., 2005; Wild and Jones, 1995). Therefore, the increase in $\Sigma_{16}$ PAHs concentration and LMW PAHs ratio in soils after nearly 20 years indicate continuing discharges of PAHs in both Jizhou district and Ninghe district. Besides, as shown in Fig. S1, in Jizhou district and Ninghe district, the percentages of soil samples contaminated and heavily contaminated by PAHs were notably higher ( $>60 \%)$ in 2018 than those ( $<25 \%)$ in 2001. The percentages of heavily contaminated soil samples in Jizhou district and Ninghe district increased from $0 \%$ to $14 \%$ and from $7 \%$ to $17 \%$, respectively. This dramatically increased trend suggests that soil PAH pollution in the studied areas need to be concerned.

In addition, it is worth noting that, from 2001 to 2018, the mean $\Sigma_{16}$ PAHs concentration in soils from Jizhou district increased by $60 \%$, while that from Ninghe district only rose by $15 \%$. The major reason may be the different geographical locations. Ninghe district is adjacent to Tianjin coastal new 
region, where there has assembled lots of industrial activities such as coking plants, coal-fired power plants, steel mills, oil exploiting and refinery, and petrochemical in the past few decades. Tianjin coastal new region could be a center of PAH emissions because industrial activities are considered to be the major PAH sources (Manariotis et al., 2011; Wolska et al., 2012; Zhang et al., 2019). Transfer from air to soil is the most important interface process for PAH flux in Tianjin, resulting in very high flux around the industrial area (Tao et al., 2003, 2004). Additionally, more than $90 \%$ of the PAHs entering into surface soils attribute to the dry and wet deposition (Wild and Jones, 1995). Therefore, the constant PAH contamination from Tianjin coastal new region may be the main reason for keeping soil PAHs in Ninghe district at a relatively high level. However, Jizhou district is located in the outer suburbs of Tianjin, far away from the areas with severe contamination of PAHs. Many studies in recent years have argued that various and scattered sources, such as industrial facility, traffic, cooking, and space heating in a city, contribute to the regional baseline deposition of PAHs, which is also influenced by the level of economic development and the degree of urbanization and industrialization (Peng et al., 2011, 2013, 2016a; Wang et al., 2015, 2018; Zhang and Chen, 2017). From 2004 to 2016, the number of Jizhou GDP increased by 500\%, and the gross product of construction industry in this district increased from 1.5 billion yuan in 2008 to 9.1 billion yuan in 2016. Thus, the relatively larger growth of PAH level in soils from Jizhou district was in part attributed to the local increasingly rapid economic development and urbanization.

Compared with the results reported in worldwide other researches, the concentrations of total PAHs in soils from Jizhou district and Ninghe district in 2018 were at middle level. As shown in Table S3, the $\Sigma_{16}$ PAHs concentrations were far lower than those in urban and rural soils from Chengdu, China (3110 $\mathrm{ng} \mathrm{g}^{-1}$ ) (Zheng et al., 2018), Bergen, Norway (6780 $\mathrm{ng} \mathrm{g}^{-1}$ ) (Haugland et al., 2008), and Glasgow, UK (11900 ng g ${ }^{-1}$ ) (Morillo et al., 2007), and comparable to those in urban soils from Changshu, China (641 $\mathrm{ng} \mathrm{g}^{-1}$ ) (Cao et al., 2017) and Torino, Italy (857 ng g ${ }^{-1}$ ) (Morillo et al., 2007$)$, as well as agricultural soils from Delhi, India (830 $\mathrm{ng} \mathrm{g}^{-1}$ ) (Agarwal et al., 2009) and Czech Republic (847 $\mathrm{ng} \mathrm{g}^{-1}$ ) (Holoubek et al., 2009). However, they were also substantially higher than those in urban, rural and agricultural soils collected globally, such as Hong Kong (54.6 ng g-1) (Zhang et al., 2006 ), Shanghai (360 $\mathrm{ng} \mathrm{g}^{-1}$ ) (Jia et al., 2017) and Xinzhou in China (202 $\mathrm{ng} \mathrm{g}^{-1}$ ) (Zhao et al., 2014), Korea (236 $\left.\mathrm{ng} \mathrm{g}^{-1}\right)$ (Nam et al., 2003), and Poland (252 ng g ${ }^{-1}$ ) (Maliszewska-Kordybach et al., 2009).

\section{Source apportionment using molecular diagnostic ratios}

PAH molecular diagnostic ratios are used to qualitatively distinguish emission sources of PAHs in many studies (Chen et al., 2018; Qi et al., 2019; Tobiszewski and Namieśnik, 2012; Wang et al., 2010; Xing et al., 2020; Yunker et al., 2002). Four diagnostic ratios were used to perform PAH source apportionment in this study (Fig. 2). In 2001, for all of samples from Jizhou district, the values of FLA/(PYR + FLA) were greater than 0.5, for 63.2\% of samples, ANT/(ANT + PHE) values were greater than 0.1 , for $57.9 \%$ of samples, IcdP/(IcdP + BghiP) values were greater than 0.5 , and for $68.4 \%$ of samples, $\mathrm{BaA} /(\mathrm{BaA}+\mathrm{CHR})$ values were in the range of $0.2-0.35$, indicating that coal and biomass combustion is the primary source of PAHs. Besides, $31.6 \%$ and $36.8 \%$ of samples having $\mathrm{BaA} /(\mathrm{BaA}+\mathrm{CHR})$ and $\mathrm{ANT} /(\mathrm{ANT}+\mathrm{PHE})$ ratio less than 0.2 and $0.1 \mathrm{imply}$ that petroleum is, to a certain degree, an important contributed source. As for Ninghe district, the values of FLA/(PYR + FLA) were greater than 0.5 for $100 \%$ of samples, IcdP/(IcdP + BghiP) values were greater than 0.5 for $71.4 \%$ of samples, and ANT/(ANT + PHE) values were greater than 0.1 for $42.9 \%$ of samples, corresponding to the important contribution of coal and biomass combustion to PAH pollutions. High percent of samples having BaA/(BaA + CHR) and ANT/(ANT + PHE) ratios less than 0.2 and 0.1 suggests that petroleum is another emission source which cannot be ignored.

For samples in Jizhou district collected in $2018,82.1 \%$ of FLA/(PYR + FLA) values were greater than 0.5, 100\% of ANT/(ANT + PHE) values were greater than $0.1,78.6 \%$ of IcdP/(IcdP + BghiP) values were greater than 0.5 , and $53.6 \%$ of $\mathrm{BaA} /(\mathrm{BaA}+\mathrm{CHR})$ values were greater than 0.35 , indicating that coal and biomass combustion is a major PAH source. As for Ninghe district, $82.8 \%$ of FLA/(PYR + FLA) values were greater than $0.5,96.6 \%$ of ANT/(ANT + $\mathrm{PHE}$ ) values were greater than $0.1,75.9 \%$ of $\mathrm{IcdP} /(\mathrm{IcdP}+\mathrm{BghiP})$ values were greater than 0.5 , and $50 \%$ of $\mathrm{BaA} /(\mathrm{BaA}+\mathrm{CHR})$ values were greater than 0.35. These results suggest that biomass and coal combustion account for the main source of PAHs.

To sum up, the diagnostic ratios preliminarily reveal a change of the major PAH sources in these two districts during the urbanization and industrialization process from 2001 to 2018 . Over this period, PAHs emissions from petrogenic origins decreased, while those from pyrogenic sources increased substantially.

\section{Source identification by positive matrix factorization (PMF) analysis}

Because of possible significant changes of molecular diagnostic ratios during the migration from sources to receptors due to different physicochemical properties of the paired species (Lang et al., 2008), some uncertainties could not be excluded only based on these ratios (Galarneau, 2008; Katsoyiannis and Breivik, 2014; Zhang et al., 2005). Therefore, USEPA PMF model 5.0 (USEPA, 2014) was introduced to further identify sources of soil PAHs and quantify their contributions in this study.

The quality of the data for each of PAHs used in the model is based on the signal-to-noise ratio and the percentage of samples with concentrations above MDLs (USEPA, 2014). Firstly, the number of soil samples in either Jizhou district or Ninghe district in 2001 was not sufficient for PMF to derive a convincing result. Secondly, with more than $50 \%$ of samples in the two districts having concentrations lower than MDLs in 2001 , DahA and BghiP were classified as bad species and were excluded from PMF. Finally, soil PAHs in Jizhou district and Ninghe district showed a similar congener pattern in both 2001 and 2018. Hence, a dataset of 33 samples and 14 species and a dataset of 57 samples and 16 species were respectively introduced into the PMF model to identify soil PAH sources in 2001 and 2018. The model was set to run from 3 to 6 factors, and each run was initialized with different starting points. The PAH profiles in factors for 2001 and 2018 are shown in Fig. 3 and Fig. 4, respectively. 
In 2001, as shown in Fig. 3, four appropriate factors were identified by the PMF analysis. Factor 1, explaining $32.1 \%$ of the total PAHs, was mainly characterized by NAP, ACE and FLO. NAP is a significant fraction of crude oil and petroleum products (Chen et al., 2013; Dahle et al., 2003; Saha et al., 2009). In addition, the dominance of 2- and 3-ring PAHs is related to petrogenic sources (Hu et al., 2013a; Olajire et al., 2005; Wang et al., 2013b). Therefore, factor 1 indicates petroleum sources.

Factor 2 accounted for $22.1 \%$ of the total PAHs and was loaded dominantly by IcdP which usually associates with vehicular emissions (Fraser et al., 1997; Harrison et al., 1996; Motelay-Massei et al., 2005), corresponding to traffic sources. Factor 3 was dominated by ANT and responsible for 12.9\% of the total PAHs. Given the fact that ANT is a marker of wood combustion source (Harrison et al., 1996), this factor is considered as biomass combustion.

Factor 4 contributed $32.9 \%$ of the total PAHs and had high loadings of PHE, FLA, PYR, CHR, and BaA. Coal combustion mainly produces PAHs dominated by 3- and 4-ring congeners (Li et al., 2012; Qu et al., 2020). FLA, PYR, BaA, CHR are typical markers for coal combustion (Duval and Friedlander, 1981; Harrison et al., 1996; Larsen and Baker, 2003; Simcik et al., 1999). Therefore, factor 4 indicates coal combustion.

As shown in Fig. 4, four appropriate factors were also identified in 2018 by the PMF analysis. Factor 1 was responsible for $18.7 \%$ of the total PAHs. This factor was predominated by ACY as well as FLA, and moderately weighted by DahA, BghiP and IcdP. ACY and FLA are predominated PAH compounds emitted by grass or wood combustion (Jenkins et al., 1996; Khalili et al., 1995; Ou et al., 2010). DahA, BghiP and IcdP have been identified as typical tracers of vehicular sources (Fraser et al., 1997; Harrison et al., 1996; Larsen and Baker, 2003; Motelay-Massei et al., 2005; Simcik et al., 1999). Thus, factor 1 is considered as petroleum and biomass combustion. The second factor accounted for $10.1 \%$ of the total PAHs and was dominated by FLO, PHE and CHR. FLO and PHE are sometimes used as indicators for coke oven sources (Duval and Friedlander, 1981; Simcik et al., 1999). Therefore, factor 2 can be closely related to coke production.

Factor 3, contributing $63.7 \%$ of the total PAHs, was loaded predominantly by NAP, ANT, BaP and DahA, and moderately weighted by ACE, FLO, ACY and BghiP. DahA, NAP, FLO, and ANT are the main tracers of diesel engines (Fraser et al., 1997; Khalili et al., 1995; Motelay-Massei et al., 2005), and ACE, ACY, FLO, BaP as well as BghiP are the main tracers of gasoline engines (Harrison et al., 1996; Khalili et al., 1995; Ravindra et al., 2008). Therefore, factor 3 indicates traffic sources.

Factor 4 contributed $7.6 \%$ of the total PAHs and had high loadings of PYR, BaA, BbF and BkF. BkF is a typical marker for industrial coal combustion (Brown and Brown, 2012). Moreover, coal combustion mainly produces PAHs dominated by 3- and 4-ring congeners (Li et al., 2012; Qu et al., 2020). Therefore, factor 4 is considered as coal combustion.

The changes for soil PAHs sources in Jizhou district and Ninghe district that happened within the past 20 years were identified according to the results calculated by PMF model. From 2001 to 2018, the contribution of coal combustion had decreased by three quarters. This is inconsistent with that obtained by molecular diagnostic ratios, which actually supports that the latter has some limitations on the source apportionment of PAHs (Galarneau, 2008; Katsoyiannis and Breivik, 2014; Zhang et al., 2005). The substantial reduction in the contribution of coal combustion may be related to the ban of coal burning for heating in winter. Furthermore, coal was the major source in the form of industrial energy in these two districts in the 2000s. However, clean energy sources, such as electricity or natural gas, have been widely expanded in China in recent years. Hence, changes in the energy structure during the industrialization process may be also responsible for this decrease. In contrast, a significant increase in the contribution of traffic sources (from $22.1 \%$ to $63.7 \%$ ) led to much higher concentrations of ANT as well as DahA and their predominance, and a corresponding rise in soil $\Sigma_{16}$ PAHs concentrations of Jizhou district and Ninghe district in 2018. The dominance of traffic sources was likely attributed to a huge surge in car use resulted from the rapid development and expansion of urbanization as well as the sustained economic growth, such as the burgeoning local vigorous tourism in Jizhou district.

\section{Health risk assessment}

The incremental lifetime cancer risk (ILCR) model was introduced to assess age- and pathway-specific potential cancer risks of soil PAHs in Jizhou district and Ninghe district. A detailed description of this model is provided in the Supplementary Content. As shown in Table 1 and Table 2, the orders of

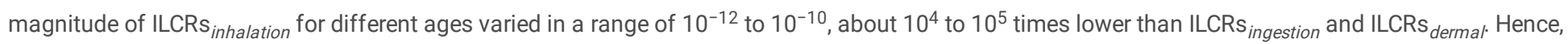
residents in Jizhou district and Ninghe district possibly exposed to soil PAHs via ingestion and dermal contact, while the exposure via inhalation was negligible.

In 2001, for children, adolescents and adults in Jizhou district, ILCRs ingestion $_{\text {and ILCRs }}$ dermal ranged from $5.91 \times 10^{-8}$ to $5.19 \times 10^{-7}$ and from $1.42 \times 10^{-7}$ to $8.84 \times 10^{-7}$, while in Ninghe district, ILCRs ingestion and ILCRs $s_{\text {dermal }}$ for these three age groups were from $6.64 \times 10^{-8}$ to $1.15 \times 10^{-6}$ and from $1.59 \times 10^{-7}$ to $1.95 \times 10^{-6}$, except one sample with ILCR values greater than $10^{-6}$. ILCRs ingestion $_{\text {and ILCRs }}$ dermal in Ninghe district were slightly higher than those in Jizhou district. Totally, the vast majority of samples in these two districts had ILCRs lower than the safe value of $1 \times 10^{-6}$, indicating health risks are generally at a safe level.

In 2018, the ILCRs of all exposure pathways for residents were relatively higher than those in 2001. For residents in Jizhou district, ILCRs ${ }_{\text {ingestion }}$ and $\mathrm{ILCRs}_{\text {dermal }}$ ranged from $5.90 \times 10^{-8}$ to $1.72 \times 10^{-6}$ and from $1.41 \times 10^{-7}$ to $2.92 \times 10^{-6}$, respectively. At 11 of the 28 samples, ILCRs dermal $_{\text {were higher than }}$ $10^{-6}$ for children, adolescents and adults, and ILCRs $s_{\text {ingestion }}$ were greater than $10^{-6}$ for children and adults. For Ninghe district, ILCRs ${ }_{\text {ingestion }}$ and ILCRs $_{\text {dermal }}$ were from $7.54 \times 10^{-8}$ to $1.18 \times 10^{-6}$ and from $1.80 \times 10^{-7}$ to $2.01 \times 10^{-6}$, respectively. For children and adolescents, ILCRs dermal $^{\text {were higher }}$ 
than $10^{-6}$ at 6 of the 29 samples, but for adults, ILCRs dermal were higher than $10^{-6}$ at 13 samples. It should be noted that there was only one sample with

ILCRs $s_{\text {ingestion }}$ greater than $10^{-6}$ for children and adults. These results indicate higher cancer risks to residents in these two districts in 2018 , with dermal contact as the chief exposure pathway. The increase in cancer risks from 2001 to 2018 occurred mainly because the alterations of PAH sources led to the predominance of DahA which has a highest TEF and therefore a strong carcinogenic potency equal to BaP. In view of the fact that DahA is considered as an indicator for the vehicular emission (Fraser et al., 1997; Motelay-Massei et al., 2005), a substitution of diesel and gasoline by clean energies in vehicles and an option of public transit over private cars should be advocated to reduce the health risks to local residents.

\section{Conclusions}

Comparisons of soil PAHs in Jizhou district and Ninghe district between 2001 and 2018 indicate that urbanization can, to a large extent, change sources, pollution levels and congener patterns of these compounds. During the past decades, the total concentrations of soil PAHs in these two rural areas increased due to the rapid urbanization, with the contributions of both 2- and 4-ring PAHs decreased substantially while 3-ring PAHs increased significantly. Instead of NAP, BbF, BkF and BaP, homologues of ANT and DahA became dominated components. Calculated data from the PMF model show that the contribution of traffic sources has nearly tripled, while coal combustion has decreased by three quarters over the past 20 years. Most importantly, predominated PAH emissions changed from coal combustion and petroleum sources to traffic sources may incur a possible substantial increase in cancer risks to the residents.

\section{Declarations}

\section{Acknowledgements}

The present study was supported by National Key R\&D Program of China (2016YFD0201201), Innovation project of CAAS, the Jiangxi Provincial Natural Science Foundation (20151BAB213038 and 20161BAB213060), and Doctor Fund of East China University of Technology (DHBK2019257).

\section{Declaration of interests}

The authors declare that they have no known competing financial interests or personal relationships that could have appeared to influence the work reported in this paper.

\The authors declare the following financial interests/personal relationships which may be considered as potential competing interests:

\section{References}

1. Agarwal, T., Khillare, P.S., Shridhar, V., Ray, S., 2009. Pattern, sources and toxic potential of PAHs in the agricultural soils of Delhi, India. Journal Of Hazardous Materials 163, 1033-1039.

2. Bozlaker, A., Muezzinoglu, A., Odabasi, M., 2008. Atmospheric concentrations, dry deposition and air-soil exchange of polycyclic aromatic hydrocarbons (PAHs) in an industrial region in Turkey. Journal Of Hazardous Materials 153, 1093-1102.

3. Brown, A.S., Brown, R.J.C., 2012. Correlations in polycyclic aromatic hydrocarbon (PAH) concentrations in UK ambient air and implications for source apportionment. Journal Of Environmental Monitoring 14, 2072-2082.

4. Cachada, A., Pato, P., Rochasantos, T.A.P., Silva, E.F.D., Duarte, A.C., 2012. Levels, sources and potential human health risks of organic pollutants in urban soils. Science Of The Total Environment 430, 184-192.

5. Cao, H., Chao, S., Qiao, L., Jiang, Y., Zeng, X., Fan, X., 2017. Urbanization-related changes in soil PAHs and potential health risks of emission sources in a township in Southern Jiangsu, China. Science Of The Total Environment 575, 692-700.

6. Chen, M., Huang, P., Chen, L., 2013. Polycyclic aromatic hydrocarbons in soils from Urumqi, China: distribution, source contributions, and potential health risks. Environmental Monitoring and Assessment 185, 5639-5651.

7. Chen, Y., Zhang, J., Zhang, F., Liu, X., Zhou, M., 2018. Contamination and health risk assessment of PAHs in farmland soils of the Yinma River Basin, China. Ecotoxicology and Environmental Safety 156, 383-390.

8. Choi, S.-D., 2014. Time trends in the levels and patterns of polycyclic aromatic hydrocarbons (PAHs) in pine bark, litter, and soil after a forest fire. Science Of The Total Environment 470-471, 1441-1449.

9. Dahle, S., Savinov, V.M., Matishov, G.G., Evenset, A., Næs, K., 2003. Polycyclic aromatic hydrocarbons (PAHs) in bottom sediments of the Kara Sea shelf, Gulf of Ob and Yenisei Bay. Science Of The Total Environment 306, 57-71.

10. Daskalakis, K.D., O'Connor, T.P., 1995. Distribution of chemical concentrations in US coastal and estuarine sediment. Marine Environmental Research 40, 381-398.

11. Desaules, A., Ammann, S., Blum, F., Brandli, R.C., Bucheli, T.D., Keller, A., 2008. PAH and PCB in soils of Switzerland-status and critical review. Journal Of Environmental Monitoring 10, 1265-1277.

12. Duval, M.M., Friedlander, S.K., 1981. Source Resolution of Polycyclic Aromatic Hydrocarbons in the Los Angeles Atmospheres: Application of a CMB with First Order Decay. U.S. EPA Report EPA-600/2-81-161, Washington, DC. 
13. Dickhut, R.M., Canuel, E.A., Gustafson, K.E., Liu, K., Arzayus, K.M., Walker, S.E., Edgecombe, G., Gaylor, M.O., MacDonald, E.H., 2000. Automotive Sources of Carcinogenic Polycyclic Aromatic Hydrocarbons Associated with Particulate Matter in the Chesapeake Bay Region. Environmental Science \& Technology 34, 4635-4640.

14. Fraser, M.P., Cass, G.R., Simoneit, B.R.T., Rasmussen, R.A., 1997. Air Quality Model Evaluation Data for Organics. 4 . $C_{2}-C_{36}$ Non-Aromatic Hydrocarbons. Environmental Science \& Technology 31, 2356-2367.

15. Galarneau, E., 2008. Source specificity and atmospheric processing of airborne PAHs: Implications for source apportionment. Atmospheric Environment 42, 8139-8149.

16. Harrison, R.M., Smith, D.J.T., Luhana, L., 1996. Source Apportionment of Atmospheric Polycyclic Aromatic Hydrocarbons Collected from an Urban Location in Birmingham, U.K. Environmental Science \& Technology 30, 825-832.

17. Harvey, R.G., 1991. Polycyclic Aromatic Hydrocarbons: Chemistry and Carcinogenicity. Cambridge University Press.

18. Haugland, T., Ottesen, R.T., Volden, T., 2008. Lead and polycyclic aromatic hydrocarbons (PAHs) in surface soil from day care centres in the city of Bergen, Norway. Environmental Pollution 153, 266-272.

19. Holoubek, I., Dusek, L., Saňka, M., Hofman, J., Cupr, P., Jarkovský, J., Zbiral, J., Klanova, J., 2009. Soil burdens of persistent organic pollutants - their levels, fate and risk. Part I. Variation of concentration ranges according to different soil uses and locations. Environmental Pollution 157, $3207-3217$.

20. Hu, N.-J., Huang, P., Liu, J.-H., Shi, X.-F., Ma, D.-Y., Liu, Y., 2013a. Source apportionment of polycyclic aromatic hydrocarbons in surface sediments of the Bohai Sea, China. Environmental Science and Pollution Research 20, 1031-1040.

21. Hu, Y., Wen, J., Wang, D., Du, X., Li, Y., 2013b. An interval dynamic multimedia fugacity (IDMF) model for environmental fate of PAHs and their source apportionment in a typical oilfield, China. Chemistry and Ecology 29, 476-488.

22. Jenkins, B.M., Jones, A.D., Turn, S.Q., Williams, R.B., 1996. Emission Factors for Polycyclic Aromatic Hydrocarbons from Biomass Burning. Environmental Science \& Technology 30, 2462-2469.

23. Jensen, H., Reimann, C., Finne, T.E., Ottesen, R.T., Arnoldussen, A., 2007. PAH-concentrations and compositions in the top $2 \mathrm{~cm}$ of forest soils along a $120 \mathrm{~km}$ long transect through agricultural areas, forests and the city of Oslo, Norway. Environmental Pollution 145, 829-838.

24. Jia, J., Bi, C., Guo, X., Wang, X., Zhou, X., Chen, Z., 2017. Characteristics, identification, and potential risk of polycyclic aromatic hydrocarbons in road dusts and agricultural soils from industrial sites in Shanghai, China. Environmental Science and Pollution Research 24, 605-615.

25. Jones, K.C., Stratford, J.A., Waterhouse, K.S., Furlong, E.T., Giger, W., Hites, R.A., Schaffner, C., Johnston, A.E., 1989. Increases in the polynuclear aromatic hydrocarbon content of an agricultural soil over the last century. Environmental Science \& Technology 23, 95-101.

26. Katsoyiannis, A., Breivik, K., 2014. Model-based evaluation of the use of polycyclic aromatic hydrocarbons molecular diagnostic ratios as a source identification tool. Environmental Pollution 184, 488-494.

27. Khalili, N.R., Scheff, P.A., Holsen, T.M., 1995. PAH source fingerprints for coke ovens, diesel and, gasoline engines, highway tunnels, and wood combustion emissions. Atmospheric Environment 29, 533-542.

28. Lang, C., Tao, S., Wang, X., Zhang, G., Fu, J., 2008. Modeling polycyclic aromatic hydrocarbon composition profiles of sources and receptors in the Pearl River Delta, China. Environmental Toxicology \& Chemistry 27, 4-9.

29. Larsen, R.K., Baker, J.E., 2003. Source Apportionment of Polycyclic Aromatic Hydrocarbons in the Urban Atmosphere: A Comparison of Three Methods. Environmental Science \& Technology 37, 1873-1881.

30. Li, W., Tian, Y., Shi, G., Guo, C., Li, X., Feng, Y., 2012. Concentrations and sources of PAHs in surface sediments of the Fenhe reservoir and watershed, China. Ecotoxicology and Environmental Safety 75, 198-206.

31. Liu, S., Xia, X., Yang, L., Shen, M., Liu, R., 2010. Polycyclic aromatic hydrocarbons in urban soils of different land uses in Beijing, China: Distribution, sources and their correlation with the city's urbanization history. Journal Of Hazardous Materials 177, 1085-1092.

32. Maliszewska-Kordybach, B., Smreczak, B., Klimkowicz-Pawlas, A., 2009. Effects of anthropopressure and soil properties on the accumulation of polycyclic aromatic hydrocarbons in the upper layer of soils in selected regions of Poland. Applied Geochemistry 24, 1918-1926.

33. Manariotis, I.D., Karapanagioti, H.K., Chrysikopoulos, C.V., 2011. Degradation of PAHs by high frequency ultrasound. Water Research 45, $2587-2594$.

34. Morillo, E., Romero, A.S., Maqueda, C., Madrid, L., Ajmonemarsan, F., Grcman, H., Davidson, C.M., Hursthouse, A., Villaverde, J., 2007. Soil pollution by PAHs in urban soils: a comparison of three European cities. Journal Of Environmental Monitoring 9, 1001-1008.

35. Motelay-Massei, A., Harner, T., Shoeib, M., Diamond, M., Stern, G., Rosenberg, B., 2005. Using passive air samplers to assess urban-rural trends for persistent organic pollutants and polycyclic aromatic hydrocarbons. 2. Seasonal trends for PAHs, PCBs, and organochlorine pesticides. Environmental Science \& Technology 39, 5763-5773.

36. Nam, J.J., Song, B.H., Eom, K.C., Lee, S.H., Smith, A., 2003. Distribution of polycyclic aromatic hydrocarbons in agricultural soils in South Korea. Chemosphere 50, 1281-1289.

37. Ni, H.-G., Qin, P.-H., Cao, S.-P., Zeng, H., 2011. Fate estimation of polycyclic aromatic hydrocarbons in soils in a rapid urbanization region, Shenzhen of China. Journal Of Environmental Monitoring 13, 313-318.

38. Nisbet, I.C.T., Lagoy, P.K., 1992. Toxic equivalency factors (TEFs) for polycyclic aromatic hydrocarbons (PAHs). Regulatory Toxicology and Pharmacology 16, 290-300.

39. Olajire, A.A., Altenburger, R., Küster, E., Brack, W., 2005. Chemical and ecotoxicological assessment of polycyclic aromatic hydrocarboncontaminated sediments of the Niger Delta, Southern Nigeria. Science Of The Total Environment 340, 123-136.

Page 7/13 
40. Ou, D., Liu, M., Cheng, S., Hou, L., Xu, S., Wang, L., 2010. Identification of the sources of polycyclic aromatic hydrocarbons based on molecular and isotopic characterization from the Yangtze estuarine and nearby coastal areas. Journal of Geographical Sciences 20, $283-294$.

41. Peng, C., Chen, W., Liao, X., Wang, M., Ouyang, Z., Jiao, W., Bai, Y., 2011. Polycyclic aromatic hydrocarbons in urban soils of Beijing: Status, sources, distribution and potential risk. Environmental Pollution 159, 802-808.

42. Peng, C., Ouyang, Z., Wang, M., Chen, W., Li, X., Crittenden, J.C., 2013. Assessing the combined risks of PAHs and metals in urban soils by urbanization indicators. Environmental Pollution 178, 426-432.

43. Peng, C., Wang, M., Chen, W., 2016a. Spatial Analysis of PAHs in Soils along an Urban-Suburban-Rural Gradient: scale effect, distribution patterns, diffusion and influencing factors. Scientific Reports 6, 37185.

44. Peng, C., Wang, M., Zhao, Y., Chen, W., 2016b. Distribution and risks of polycyclic aromatic hydrocarbons in suburban and rural soils of Beijing with various land uses. Environmental Monitoring and Assessment 188, 162.

45. Qi, H., Chen, X., Du, Y., Niu, X., Guo, F., Li, W., 2019. Cancer risk assessment of soils contaminated by polycyclic aromatic hydrocarbons in Shanxi, China. Ecotoxicology and Environmental Safety 182, 109381.

46. Qu, Y., Gong, Y., Ma, J., Wei, H., Liu, Q., Liu, L., Wu, H., Yang, S., Chen, Y., 2020. Potential sources, influencing factors, and health risks of polycyclic aromatic hydrocarbons (PAHs) in the surface soil of urban parks in Beijing, China. Environmental Pollution 260, 114016.

47. Ravindra, K., Sokhi, R., Van Grieken, R., 2008. Atmospheric polycyclic aromatic hydrocarbons: Source attribution, emission factors and regulation. Atmospheric Environment 42, 2895-2921.

48. Saha, M., Togo, A., Mizukawa, K., Murakami, M., Takada, H., Zakaria, M.P., Chiem, N.H., Tuyen, B.C., Prudente, M., Boonyatumanond, R., Sarkar, S.K., Bhattacharya, B., Mishra, P., Tana, T.S., 2009. Sources of sedimentary PAHs in tropical Asian waters: Differentiation between pyrogenic and petrogenic sources by alkyl homolog abundance. Marine Pollution Bulletin 58, 189-200.

49. Santodonato, J., Howard, P., Basu, D., 1981. Health and ecological assessment of polynuclear aromatic hydrocarbons. Journal of environmental pathology and toxicology 5, 1-364.

50. Shi, R., Li, X., Yang, Y., Fan, Y., Zhao, Z., 2021. Contamination and human health risks of polycyclic aromatic hydrocarbons in surface soils from Tianjin coastal new region, China. Environmental Pollution 268, 115938.

51. Simcik, M.F., Eisenreich, S.J., Lioy, P.J., 1999. Source apportionment and source/sink relationships of PAHs in the coastal atmosphere of Chicago and Lake Michigan. Atmospheric Environment 33, 5071-5079.

52. Sun, G.-D., Jin, J.-H., Xu, Y., Zhong, Z.-P., Liu, Y., Liu, Z.-P., 2014. Isolation of a high molecular weight polycyclic aromatic hydrocarbon-degrading strain and its enhancing the removal of HMW-PAHs from heavily contaminated soil. International Biodeterioration \& Biodegradation 90, 23-28.

53. Tao, S., Cao, H., Liu, W., Li, B., Cao, J., Xu, F., Wang, X., Coveney, R.M., Shen, W., Qin, Baoping, 2003. Fate Modeling of Phenanthrene with Regional Variation in Tianjin, China. Environmental Science \& Technology 37, 2453-2459.

54. Tao, S., Cui, Y.H., Xu, F., Li, B., Cao, J., Liu, W., Schmitt, G., Wang, X., Shen, W.R., Qing, B.P., 2004. Polycyclic aromatic hydrocarbons (PAHs) in agricultural soil and vegetables from Tianjin. Science Of The Total Environment 320, 11-24.

55. Tobiszewski, M., Namieśnik, J., 2012. PAH diagnostic ratios for the identification of pollution emission sources. Environmental Pollution 162, 110119.

56. USEPA, 2014. EPA Positive Matrix Factorization (PMF) 5.0 Fundamentals and User Guide.

57. Van Metre, P.C., Mahler, B.J., Furlong, E.T., 2000. Urban Sprawl Leaves Its PAH Signature. Environmental Science \& Technology 34, $4064-4070$.

58. Wang, C., Shaohua, W.U., Zhou, S., Shi, Y., Song, J., 2017. Characteristics and Source Identification of Polycyclic Aromatic Hydrocarbons (PAHs) in Urban Soils: A Review. Pedosphere 27, 17-26.

59. Wang, C., Wu, S., Zhou, S., Wang, H., Li, B., Chen, H., Yu, Y., Shi, Y., 2015. Polycyclic aromatic hydrocarbons in soils from urban to rural areas in Nanjing: Concentration, source, spatial distribution, and potential human health risk. Science Of The Total Environment 527-528, 375-383.

60. Wang, C., Zhou, S., Song, J., Wu, S., 2018. Human health risks of polycyclic aromatic hydrocarbons in the urban soils of Nanjing, China. Science Of The Total Environment 612, 750-757.

61. Wang, J., Zhu, C., Chen, T., 2013a. PAHs in the Chinese environment: levels, inventory mass, source and toxic potency assessment. Environmental Science: Processes \& Impacts 15, 1104-1112.

62. Wang, W., Simonich, S., Giri, B., Chang, Y., Zhang, Y., Jia, Y., Tao, S., Wang, R., Wang, B., Li, W., Cao, J., Lu, X., 2011. Atmospheric concentrations and air-soil gas exchange of polycyclic aromatic hydrocarbons (PAHs) in remote, rural village and urban areas of Beijing-Tianjin region, North China. Science Of The Total Environment 409, 2942-2950.

63. Wang, W., Simonich, S.L.M., Xue, M., Zhao, J., Zhang, N., Wang, R., Cao, J., Tao, S., 2010. Concentrations, sources and spatial distribution of polycyclic aromatic hydrocarbons in soils from Beijing, Tianjin and surrounding areas, North China. Environmental Pollution 158, $1245-1251$.

64. Wang, X., Ren, L., Dai, Y., Chen, J., Piao, X., Tao, S., 2003. Contents of PAH compounds in different types of soils in Tianjin area. Geographical Research 22, 360-366 (in Chinese).

65. Wang, X.-T., Miao, Y., Zhang, Y., Li, Y.-C., Wu, M.-H., Yu, G., 2013b. Polycyclic aromatic hydrocarbons (PAHs) in urban soils of the megacity Shanghai: Occurrence, source apportionment and potential human health risk. Science Of The Total Environment 447, 80-89.

66. Wang, Y., Tian, Z., Zhu, H., Cheng, Z., Kang, M., Luo, C., Li, J., Zhang, G., 2012. Polycyclic aromatic hydrocarbons (PAHs) in soils and vegetation near an e-waste recycling site in South China: Concentration, distribution, source, and risk assessment. Science Of The Total Environment $439,187-193$.

Page $8 / 13$ 
67. Wang, Z., Chen, J., Qiao, X., Yang, P., Tian, F., Huang, L., 2007. Distribution and sources of polycyclic aromatic hydrocarbons from urban to rural soils: a case study in Dalian, China. Chemosphere 68, 965-971.

68. Waqas, M., Khan, S., Chao, C., Shamshad, I., Qamar, Z., Khan, K., 2014. Quantification of PAHs and health risk via ingestion of vegetable in Khyber Pakhtunkhwa Province, Pakistan. Science Of The Total Environment 497-498, 448-458.

69. Wilcke, W., 2007. Global patterns of polycyclic aromatic hydrocarbons (PAHs) in soil. Geoderma 141, 157-166.

70. Wilcke, W., Krauss, M., Safronov, G., Fokin, A.D., Kaupenjohann, M., 2005. Polycyclic Aromatic Hydrocarbons (PAHs) in Soils of the Moscow RegionConcentrations, Temporal Trends, and Small-Scale Distribution. Journal Of Environmental Quality 34, 1581-1590.

71. Wild, S.R., Jones, K.C., 1995. Polynuclear aromatic hydrocarbons in the United Kingdom environment: A preliminary source inventory and budget. Environmental Pollution 88, 91-108.

72. Wolska, L., Mechlinska, A., Rogowska, J., Namieśnik, J., 2012. Sources and Fate of PAHs and PCBs in the Marine Environment. Critical Reviews In Environmental Science and Technology 42, 1172-1189.

73. Wu, S., Zhou, S., Bao, H., Chen, D., Wang, C., Li, B., Tong, G., Yuan, Y., Xu, B., 2019. Improving risk management by using the spatial interaction relationship of heavy metals and PAHs in urban soil. Journal Of Hazardous Materials 364, 108-116.

74. Xing, X., Mao, Y., Hu, T., Tian, Q., Chen, Z., Liao, T., Zhang, Z., Zhang, J., Gu, Y., Bhutto, S.U.A., 2020. Spatial distribution, possible sources and health risks of PAHs and OCPs in surface soils from Dajiuhu Sub-alpine Wetland, central China. Journal Of Geochemical Exploration $208,106393$.

75. Yunker, M.B., Macdonald, R.W., Vingarzan, R., Mitchell, R.H., Goyette, D., Sylvestre, S., 2002. PAHs in the Fraser River basin: a critical appraisal of PAH ratios as indicators of PAH source and composition. Organic Geochemistry 33, 489-515.

76. Zhang, H., Luo, Y.M., Wong, M.H., Zhao, Q.G., Zhang, G., 2006. Distributions and Concentrations of PAHs in Hong Kong Soils. Environmental Pollution 141, 107-114.

77. Zhang, P., Chen, Y., 2017. Polycyclic aromatic hydrocarbons contamination in surface soil of China: A review. Science Of The Total Environment $605-$ 606, 1011-1020.

78. Zhang, X.L., Tag, S., Liu, W.X., Yang, Y., Zuo, Q., 2005. Source diagnostics of polycyclic aromatic hydrocarbons based on species ratios: a multimedia approach. Environmental Science \& Technology 39, 9109-9114.

79. Zhang, Y., Peng, C., Guo, Z., Xiao, X., Xiao, R., 2019. Polycyclic aromatic hydrocarbons in urban soils of China: Distribution, influencing factors, health risk and regression prediction. Environmental Pollution 254, 112930.

80. Zhao, L., Hou, H., Shangguan, Y., Cheng, B., Xu, Y., Zhao, R., Zhang, Y., Hua, X., Huo, X., Zhao, X., 2014. Occurrence, sources, and potential human health risks of polycyclic aromatic hydrocarbons in agricultural soils of the coal production area surrounding Xinzhou, China. Ecotoxicology and Environmental Safety 108, 120-128.

81. Zheng, H., Xing, X., Hu, T., Zhang, Y., Zhang, J., Zhu, G., Li, Y., Qi, S., 2018. Biomass burning contributed most to the human cancer risk exposed to the soil-bound PAHs from Chengdu Economic Region, western China. Ecotoxicology and Environmental Safety 159, 63-70.

82. Zuo, Q., Duan, Y., Yang, Y., Wang, X., Tao, S., 2007. Source apportionment of polycyclic aromatic hydrocarbons in surface soil in Tianjin, China. Environmental Pollution 147, 303-310.

\section{Tables}

Table 1

Age-specific potential cancer risk via exposure to soil PAHs in 2001

\begin{tabular}{|c|c|c|c|c|c|c|c|c|c|c|}
\hline \multirow[t]{2}{*}{ District } & & \multicolumn{3}{|l|}{ Childhood } & \multicolumn{3}{|l|}{ Adolescence } & \multicolumn{3}{|l|}{ Adulthood } \\
\hline & & ILCR $_{\text {ingestion }}$ & $\mathrm{ILCR}_{\text {dermal }}$ & $\mathrm{ILCR}_{\text {inhalation }}$ & $\mathrm{ILCR}_{\text {ingestion }}$ & ILCR $_{\text {dermal }}$ & $\mathrm{ILCR}_{\text {inhalation }}$ & $\mathrm{ILCR}_{\text {ingestion }}$ & ILCR $_{\text {dermal }}$ & $\mathrm{ILCR}_{\text {inhalation }}$ \\
\hline \multirow[t]{3}{*}{ Jizhou } & Mean & $2.84 \times 10^{-7}$ & $\begin{array}{l}3.54 \times \\
10^{-7}\end{array}$ & $\begin{array}{l}6.01 \times 10^{-} \\
12\end{array}$ & $1.48 \times 10^{-7}$ & $\begin{array}{l}3.69 \times \\
10^{-7}\end{array}$ & $\begin{array}{l}1.02 \times 10^{-} \\
11\end{array}$ & $2.72 \times 10^{-7}$ & $\begin{array}{l}4.84 \times \\
10^{-7}\end{array}$ & $\begin{array}{l}1.85 \times 10^{-} \\
11\end{array}$ \\
\hline & Min. & $1.14 \times 10^{-7}$ & $\begin{array}{l}1.42 \times \\
10^{-7}\end{array}$ & $\begin{array}{l}2.40 \times 10^{-} \\
12\end{array}$ & $5.91 \times 10^{-8}$ & $\begin{array}{l}1.47 \times \\
10^{-7}\end{array}$ & $\begin{array}{l}4.06 \times 10^{-} \\
12\end{array}$ & $1.09 \times 10^{-7}$ & $\begin{array}{l}1.93 \times \\
10^{-7}\end{array}$ & $\begin{array}{l}7.38 \times 10^{-} \\
12\end{array}$ \\
\hline & Max. & $5.19 \times 10^{-7}$ & $\begin{array}{l}6.47 \times \\
10^{-7}\end{array}$ & $\begin{array}{l}1.10 \times 10^{-} \\
11\end{array}$ & $2.71 \times 10^{-7}$ & $\begin{array}{l}6.75 \times \\
10^{-7}\end{array}$ & $\begin{array}{l}1.86 \times 10^{-} \\
11\end{array}$ & $4.98 \times 10^{-7}$ & $\begin{array}{l}8.84 \times \\
10^{-7}\end{array}$ & $\begin{array}{l}3.38 \times 10^{-} \\
11\end{array}$ \\
\hline \multirow[t]{3}{*}{ Ninghe } & Mean & $3.59 \times 10^{-7}$ & $\begin{array}{l}4.47 \times \\
10^{-7}\end{array}$ & $\begin{array}{l}7.58 \times 10^{-} \\
12\end{array}$ & $1.87 \times 10^{-7}$ & $\begin{array}{l}4.66 \times \\
10^{-7}\end{array}$ & $\begin{array}{l}1.28 \times 10^{-} \\
11\end{array}$ & $3.44 \times 10^{-7}$ & $\begin{array}{l}6.11 \times \\
10^{-7}\end{array}$ & $\begin{array}{l}2.33 \times 10^{-} \\
11\end{array}$ \\
\hline & Min. & $1.27 \times 10^{-7}$ & $\begin{array}{l}1.59 \times \\
10^{-7}\end{array}$ & $\begin{array}{l}2.69 \times 10^{-} \\
12\end{array}$ & $6.64 \times 10^{-8}$ & $\begin{array}{l}1.66 \times \\
10^{-7}\end{array}$ & $\begin{array}{l}4.56 \times 10^{-} \\
12\end{array}$ & $1.22 \times 10^{-7}$ & $\begin{array}{l}2.17 \times \\
10^{-7}\end{array}$ & $\begin{array}{l}8.29 \times 10^{-} \\
12\end{array}$ \\
\hline & Max. & $1.15 \times 10^{-6}$ & $\begin{array}{l}1.43 \times \\
10^{-6}\end{array}$ & $\begin{array}{l}2.42 \times 10^{-} \\
11\end{array}$ & $5.97 \times 10^{-7}$ & $\begin{array}{l}1.49 \times \\
10^{-6}\end{array}$ & $\begin{array}{l}4.10 \times 10^{-} \\
11\end{array}$ & $1.10 \times 10^{-6}$ & $\begin{array}{l}1.95 \times \\
10^{-6}\end{array}$ & $\begin{array}{l}7.45 \times 10^{-} \\
11\end{array}$ \\
\hline
\end{tabular}


Table 2

Age-specific potential cancer risk via exposure to soil PAHs in 2018

\begin{tabular}{|c|c|c|c|c|c|c|c|c|c|c|}
\hline \multirow[t]{2}{*}{ District } & & \multicolumn{3}{|l|}{ Childhood } & \multicolumn{3}{|l|}{ Adolescence } & \multicolumn{3}{|l|}{ Adulthood } \\
\hline & & $\mathrm{ILCR}_{\text {ingestion }}$ & $\mathrm{ILCR}_{\text {dermal }}$ & $\mathrm{ILCR}_{\text {inhalation }}$ & $\mathrm{ILCR}_{\text {ingestion }}$ & $\mathrm{ILCR}_{\text {dermal }}$ & $\mathrm{ILCR}_{\text {inhalation }}$ & $\mathrm{ILCR}_{\text {ingestion }}$ & $\mathrm{ILCR}_{\text {dermal }}$ & $\mathrm{ILCR}_{\text {inhalation }}$ \\
\hline \multirow[t]{3}{*}{ Jizhou } & Mean & $7.38 \times 10^{-7}$ & $\begin{array}{l}9.20 \times \\
10^{-7}\end{array}$ & $\begin{array}{l}1.56 \times 10^{-} \\
11\end{array}$ & $3.84 \times 10^{-7}$ & $\begin{array}{l}9.58 \times \\
10^{-7}\end{array}$ & $\begin{array}{l}2.64 \times 10^{-} \\
11\end{array}$ & $7.07 \times 10^{-7}$ & $\begin{array}{l}1.26 \times \\
10^{-6}\end{array}$ & $\begin{array}{l}4.80 \times 10^{-} \\
11\end{array}$ \\
\hline & Min. & $1.13 \times 10^{-7}$ & $\begin{array}{l}1.41 \times \\
10^{-7}\end{array}$ & $\begin{array}{l}2.40 \times 10^{-} \\
12\end{array}$ & $5.90 \times 10^{-8}$ & $\begin{array}{l}1.47 \times \\
10^{-7}\end{array}$ & $\begin{array}{l}4.05 \times 10^{-} \\
12\end{array}$ & $1.09 \times 10^{-7}$ & $\begin{array}{l}1.93 \times \\
10^{-7}\end{array}$ & $\begin{array}{l}7.37 \times 10^{-} \\
12\end{array}$ \\
\hline & Max. & $1.72 \times 10^{-6}$ & $\begin{array}{l}2.14 \times \\
10^{-6}\end{array}$ & $\begin{array}{l}3.63 \times 10^{-} \\
11\end{array}$ & $8.95 \times 10^{-7}$ & $\begin{array}{l}2.23 \times \\
10^{-6}\end{array}$ & $\begin{array}{l}6.14 \times 10^{-} \\
11\end{array}$ & $1.65 \times 10^{-6}$ & $\begin{array}{l}2.92 \times \\
10^{-6}\end{array}$ & $\begin{array}{l}1.12 \times 10^{-} \\
10\end{array}$ \\
\hline \multirow[t]{3}{*}{ Ninghe } & Mean & $5.23 \times 10^{-7}$ & $\begin{array}{l}6.52 \times \\
10^{-7}\end{array}$ & $\begin{array}{l}1.11 \times 10^{-} \\
11\end{array}$ & $2.72 \times 10^{-7}$ & $\begin{array}{l}6.79 \times \\
10^{-7}\end{array}$ & $\begin{array}{l}1.87 \times 10^{-} \\
11\end{array}$ & $5.01 \times 10^{-7}$ & $\begin{array}{l}8.90 \times \\
10^{-7}\end{array}$ & $\begin{array}{l}3.40 \times 10^{-} \\
11\end{array}$ \\
\hline & Min. & $1.45 \times 10^{-7}$ & $\begin{array}{l}1.80 \times \\
10^{-7}\end{array}$ & $\begin{array}{l}3.06 \times 10^{-} \\
12\end{array}$ & $7.54 \times 10^{-8}$ & $\begin{array}{l}1.88 \times \\
10^{-7}\end{array}$ & $\begin{array}{l}5.17 \times 10^{-} \\
12\end{array}$ & $1.39 \times 10^{-7}$ & $\begin{array}{l}2.46 \times \\
10^{-7}\end{array}$ & $\begin{array}{l}9.40 \times 10^{-} \\
12\end{array}$ \\
\hline & Max. & $1.18 \times 10^{-6}$ & $\begin{array}{l}1.47 \times \\
10^{-6}\end{array}$ & $\begin{array}{l}2.50 \times 10^{-} \\
11\end{array}$ & $6.15 \times 10^{-7}$ & $\begin{array}{l}1.53 \times \\
10^{-6}\end{array}$ & $\begin{array}{l}4.22 \times 10^{-} \\
11\end{array}$ & $1.13 \times 10^{-6}$ & $\begin{array}{l}2.01 \times \\
10^{-6}\end{array}$ & $\begin{array}{l}7.68 \times 10^{-} \\
11\end{array}$ \\
\hline
\end{tabular}

\section{Figures}
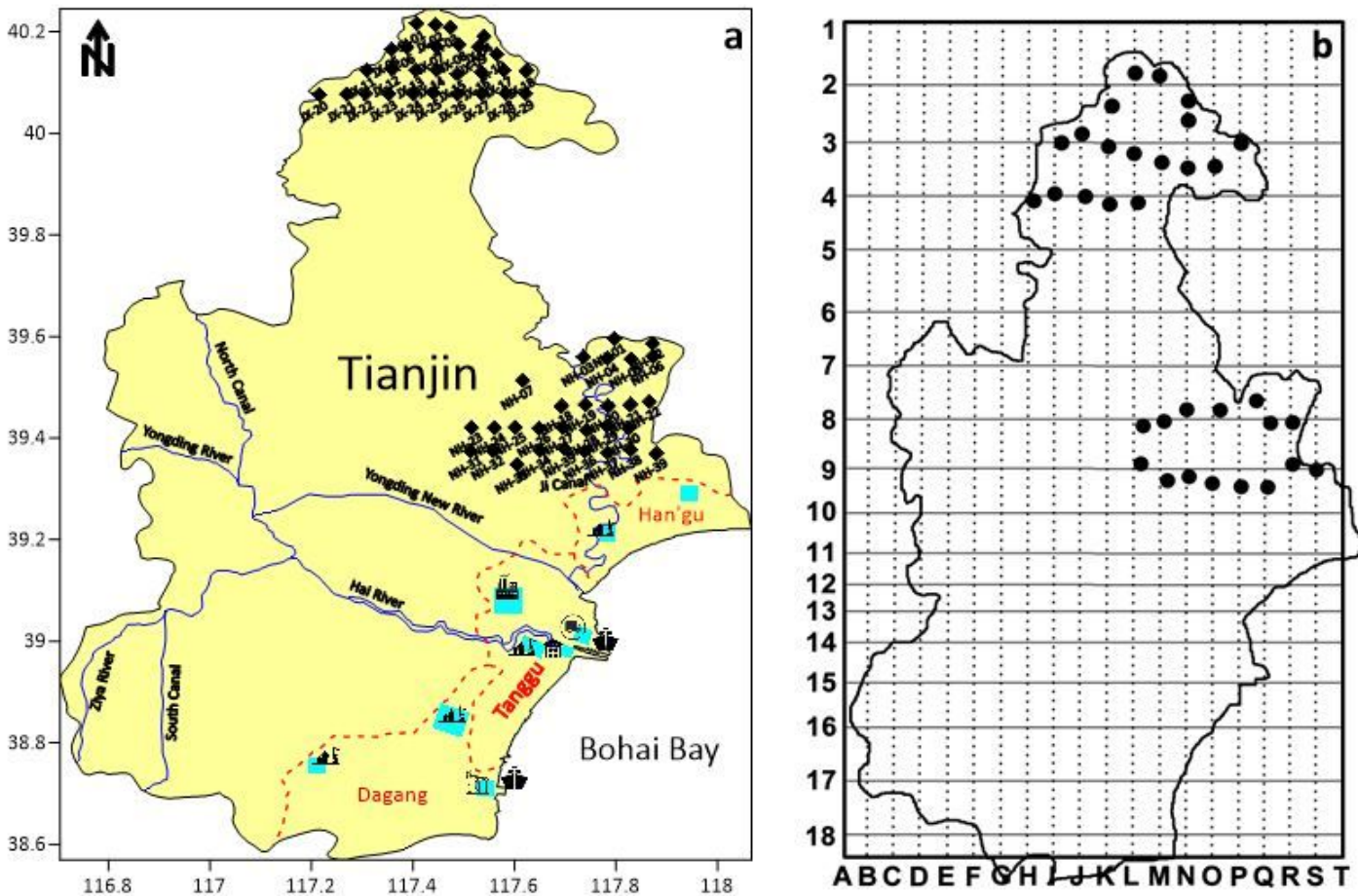

Figure 1

Map of the study area and the sampling site in 2018 (a), and 2001 (b) (modified from a study that published by Wang et al. (2003)). Industrial areas are marked in cyan. Note: The designations employed and the presentation of the material on this map do not imply the expression of any opinion whatsoever on the part of Research Square concerning the legal status of any country, territory, city or area or of its authorities, or concerning the delimitation of its frontiers or boundaries. This map has been provided by the authors. 

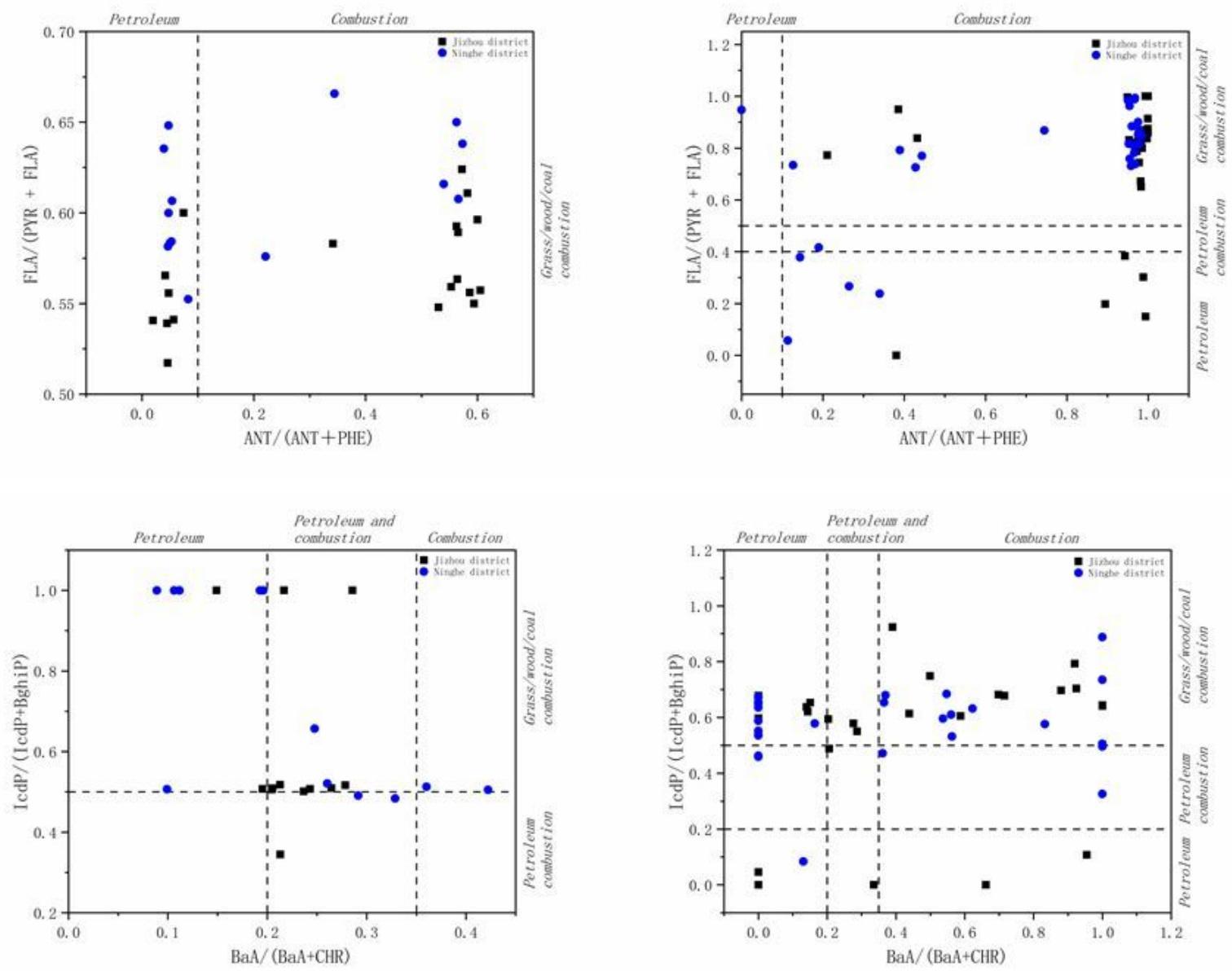

Figure 2

Plots of PAH molecular diagnostic ratios in 2001 (left) and 2018 (right) 

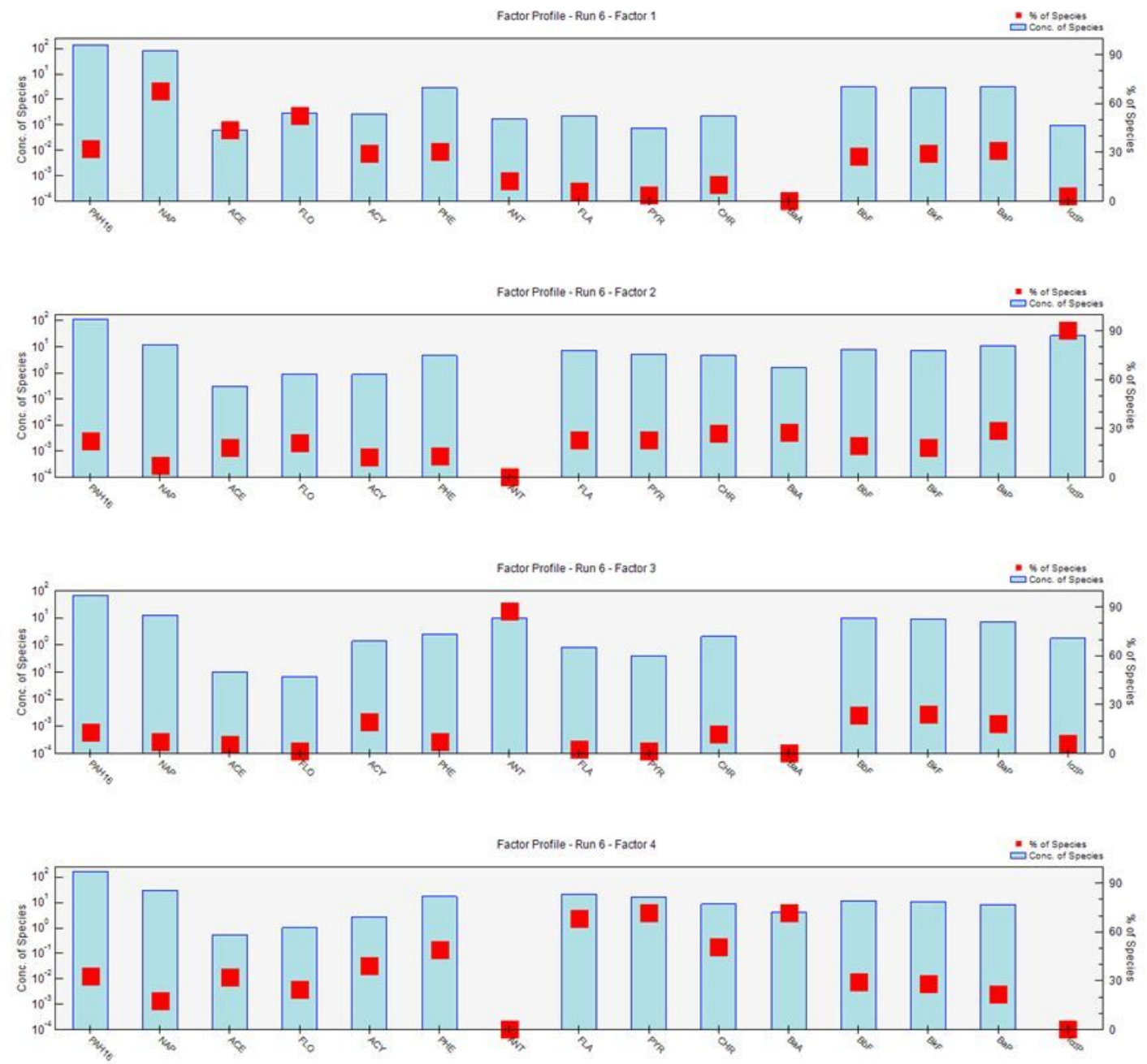

Figure 3

Source profiles of each factor in 2001 obtained from PMF model 


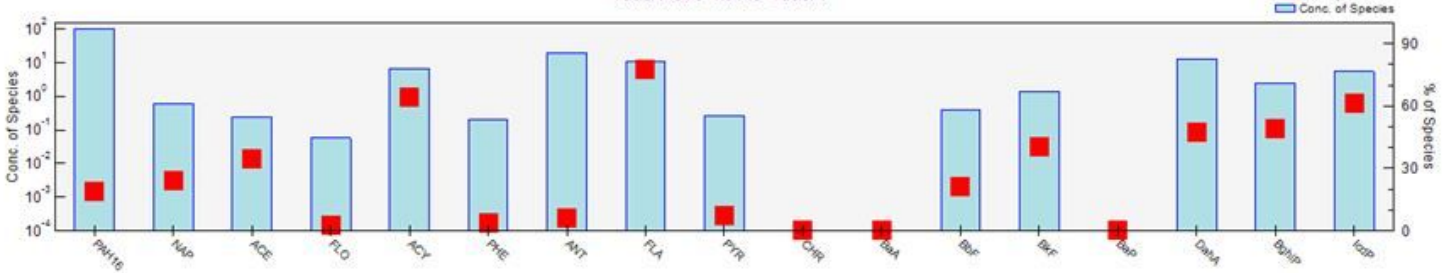

Factor Profile - Run 18 - Factor 2 DO or specers.
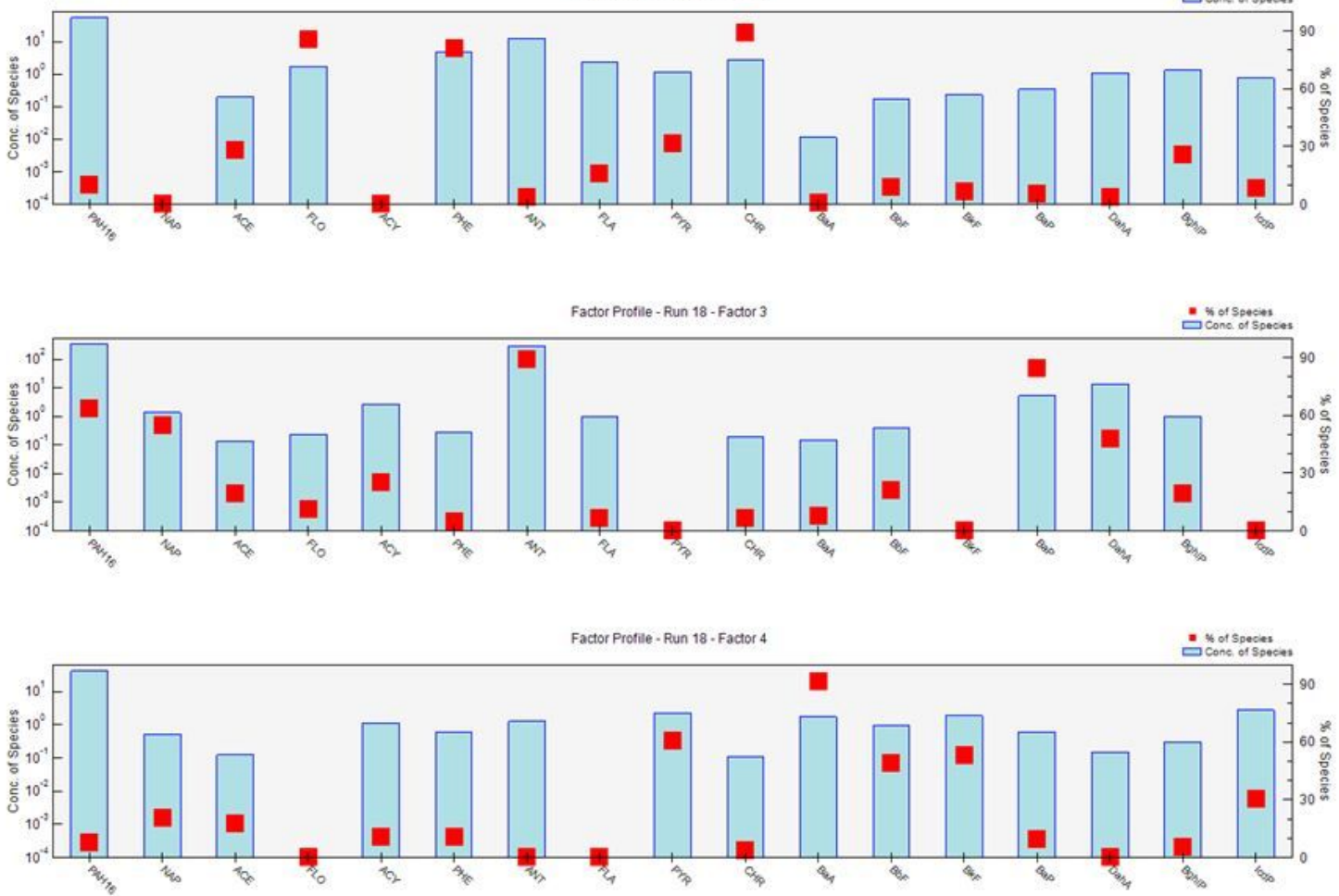

Figure 4

Source profiles of each factor in 2018 obtained from PMF model

\section{Supplementary Files}

This is a list of supplementary files associated with this preprint. Click to download.

- Supplementarycontent.doc 